\title{
PRELIMINARY GEOTHERMAL INVESTIGATION IN THE BASIN OF KATERINI (NORTHERN GREECE)
}

\author{
Papachristou M. ${ }^{1}$, Arvanitis A. ${ }^{2}$ and Kolios N. ${ }^{3}$ \\ ${ }^{1}$ Aristotle University of Thessaloniki, Department of Geology, 54124, Thessaloniki, Greece, \\ mariap@geo.auth.gr \\ ${ }^{2}$ Institute of Geology and Mineral Exploration, $1^{\text {st }}$ Spirou Louis St., Olympic Village, 13677, \\ Acharnae,Greece, arvanitis@igme.gr \\ ${ }^{3}$ Geothermiki Hellas Ltd, Neo Erasmio, 67200,Xanthi, Greece, kolios@agrecofarm.gr
}

\begin{abstract}
This paper describes the results of the preliminary surface geothermal exploration conducted by IGME in the basin of Katerini (Northern Greece). It mainly regards temperature measurements at the wellhead of 73 wells and in the interior of five boreholes, as well as sampling and chemical analyses from 18 selected sites. Based on the collected data, three sub-regions of geothermal interest can be distinguished, the most important of which is the area of Kato Agios Ioannis (to the south of the basin), with temperatures around $27^{\circ} \mathrm{C}$ at the depth of $340 \mathrm{~m}$. Nonetheless, the detailed geothermal investigation of this basin requires further systematic research as well as the drilling of at least one deep geothermal exploration borehole.

Keywords: exploration, temperature, geothermal gradient, isotherms.

\section{Пєрі́⿱亠乂 $\psi \eta$}

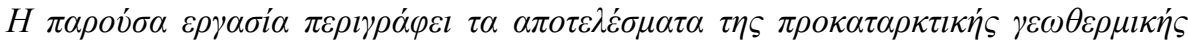

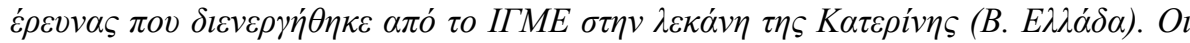

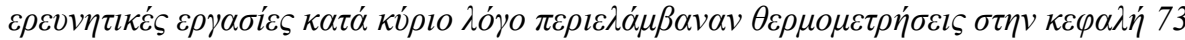

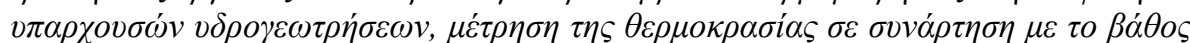

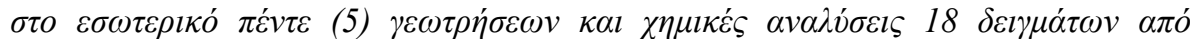

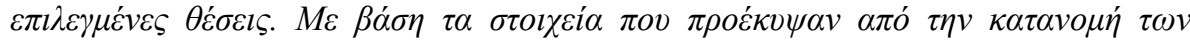

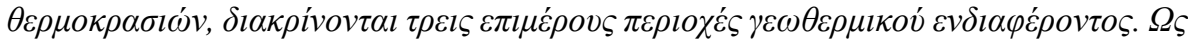

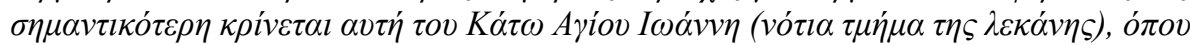

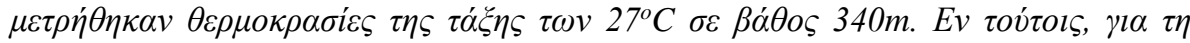

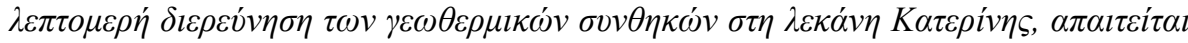

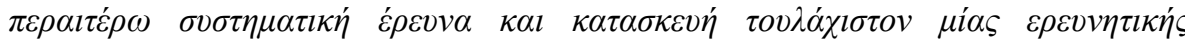


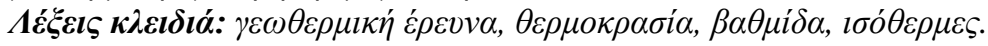

\section{Introduction}

The geothermal exploration in Greece has revealed the significant geothermal potential of the country, attributed mainly to its specific geotectonic conditions. High enthalpy geothermal systems 
have been discovered in the active South Aegean Volcanic Arc, whereas the systematic geothermal research has identified numerous low and medium enthalpy fields around the country.

The exploitation of geothermal energy has proved to bring significant economic and environmental benefits. The heating of buildings, agricultural and spa facilities, pools, etc., could be achieved with low cost by utilizing low enthalpy $\left(25-90^{\circ} \mathrm{C}\right)$ geothermal fluids. In addition, the use of the groundsource heat pumps (GSHP) facilitates the exploitation of lower temperature fluids $\left(<25^{\circ} \mathrm{C}\right)$ from shallow reservoirs in many of the above applications.

The basin of Katerini constitutes basically a rural region, with $38 \%$ of the total area being agricultural land. On the other hand, the coastal places are a well-known tourist destination, so, the most important economic activities are related to the agricultural and tourism sectors. For that reason, the investigation of the geothermal conditions in the area could signify several possibilities for effectively exploiting the available geothermal energy in relative applications, which, in turn, could considerably support the local economy and result in positive socioeconomic impacts.

\section{General characteristics of the study area}

The basin of Katerini belongs to the Pieria Prefecture and forms the southern part of the broader Thessaloniki basin (Central Macedonia, Northern Greece). It is bounded to the north by Aliakmon River, southwards by the alluvial fans of Mt. Olympus, to the east by Thermaikos Gulf and to the west by Pieria Mt. (Fig. 1).

Based on the topography, three elevation zones can be distinguished: (i) the mountainous ( $>500 \mathrm{~m})$, (ii) the hilly $(100-500 \mathrm{~m})$, and (iii) the coastal plain $(0-100 \mathrm{~m})$ areas. The plain terrains cover almost $40 \%$ of the basin, while the coastline is more than $70 \mathrm{~km}$ long. The geothermal investigation focused on the hilly and coastal zones. The hydrographic network is well developed with numerous branches. Its structure is controlled by the local geologic conditions and is indicative of the tectonic activity in the area.

The climate in the broader area of Katerini basin is mild with cold winter and dry hot summer (Kottek et al., 2006). The climatic conditions are more temperate near the coast, but severe winters are common in the western (mountainous) parts of the basin. The mean annual air temperature at the basin is $15.5^{\circ} \mathrm{C}$ in the plain areas and changes by $0.61^{\circ} \mathrm{C} / 100 \mathrm{~m}$ (Tzimourtas, 2001).

\section{Geological and Tectonic setting}

The basement of the study area is formed by the metamorphic rocks of Almopia sub-zone, which is mainly characterized by the presence of Upper Jurassic ophiolitic formations as well as by deep-sea sedimentary and volcano-sedimentary series (Mountrakis, 1985). Pelagonian metamorphic formations (schists, gneisses, and marbles with overthrusting ophiolitic complexes) are found at the western margin of the basin.

The investigated area is covered by Neogene and Quaternary deposits of 1000-1500m thickness that progressively filled up the basin. The Neogene formations consist of alluvial, fluvial, lacustrine and fluvio-lacustrine sediments, such as conglomerates, lignites, clay, marls, sand and limestones, that occupy the central hilly part of the basin. According to Sylvestrou (2002), the Neogene sediments can be classified in eight (8) formations, based on lithologic data and paleontological evidence: (1) Elatochori Fm, (2) Moschopotamos Fm, (3) Sykea Fm, (4) Ryakia Fm, (5) Lagorachi Fm, (6) Sfendami Fm, (7) Makrygialos Fm, and (8) Lofos Fm (Fig.1). The Formations of Sykea, Ryakia, Lagorachi and Sfendami occupy the largest part of the basin, whereas Elatochori and Moschopotamos Formations outcrop only its south-western border. The most recent Formations (Makrygialos and Lofos) are found at the northern and southern part of the basin, respectively. The detailed Neogene lithology has been described by Sylvestrou (2002). 


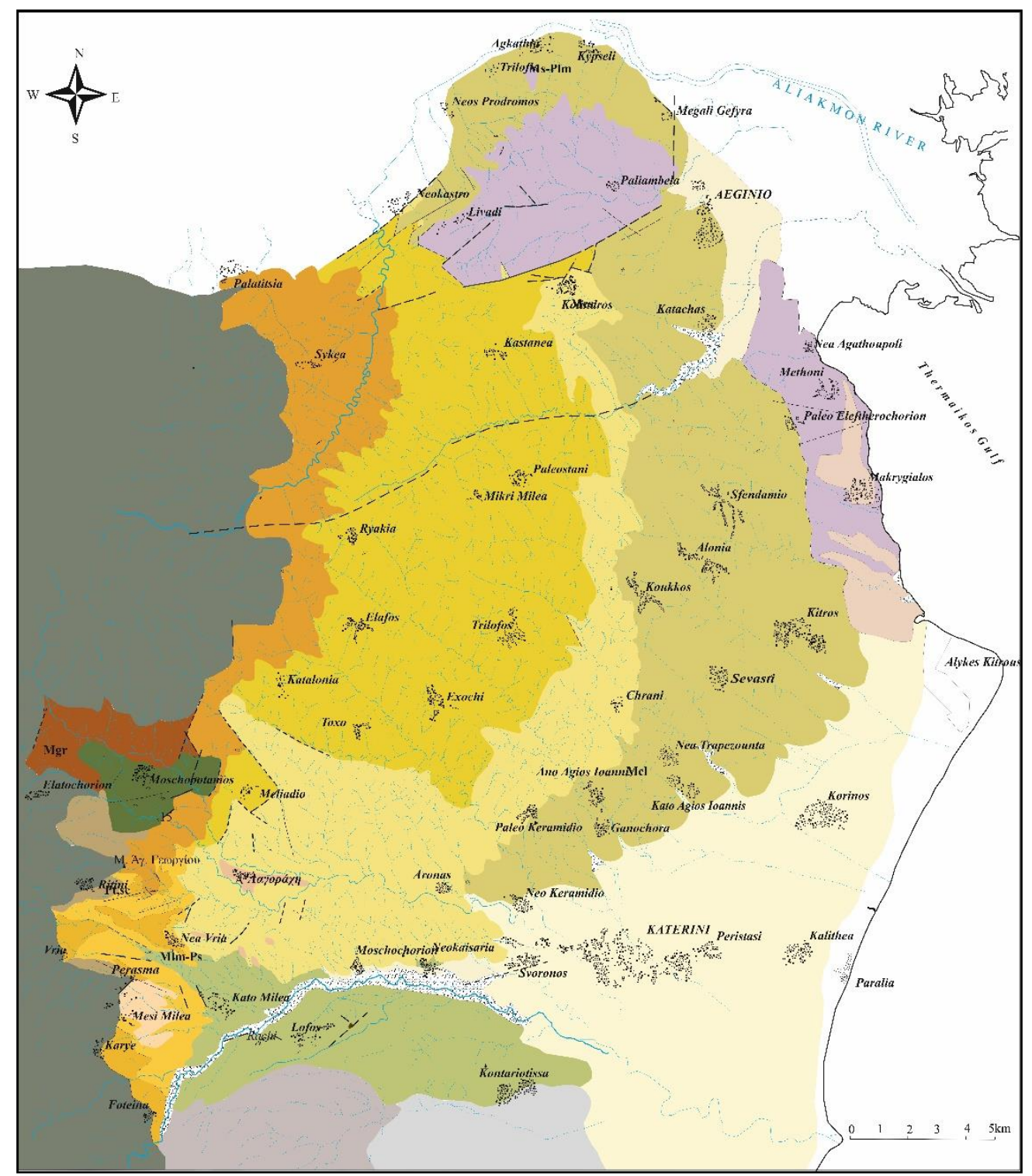

Holocene

\section{LEGEND}

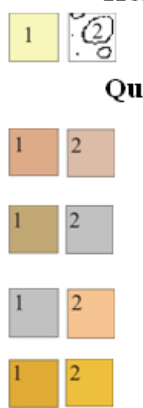

(1) Coarse material (2)

Alluvials with sand, clay, etc

Quaternary

(1) Alternations of red clay
and sand, (2) red-brown clay

(1) Scree (2) Coarse clastic sediments

(1) Olympos fans (2) Red beds

(1), (2) Fans with pebbles mixed with coarse clastic material

\begin{tabular}{|l|}
\multicolumn{1}{c}{ Neogene } \\
\hline \\
Lofos Fm: sand, pebbles, \\
marls, limestones. \\
\hline Makrygialos Fm: sand, with \\
volcanoclastics, clay, \\
sandstones, conglomerates \\
\hline Sfendami Fm: Fossiliferous \\
green clays with marl and \\
marly limestone \\
Lagorachi Fm: Sand with \\
grits. Conglomerates with \\
sandy filling \\
\hline Ryakia Fm: Sand with sandstone \\
lenses. Green clays with grits. \\
Lignitic intercalations
\end{tabular}

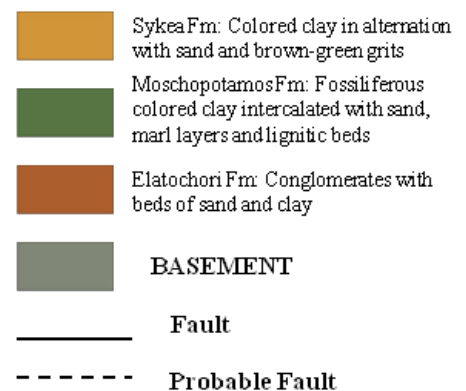

Figure 1 - Geologic map of Katerini basin (modified from Sylvestrou, 2002). 
The Quaternary sediments cover the plain part of the basin and mostly consist of sand and clay with coarse material (gravels and pebbles). They have been deposited in unconformity over the Neogene sediments and their thickness ranges from 15 to 60m (Benda and Stevens, 1981; Sylvestrou, 2002).

The basin is generally characterized by recent and intense tectonic activity. Small NW-SE 'en echelon' faults have been found at the WSW boundaries, while normal NE-SW dislocation faults have affected the area southwards of Moschopotamos. At the north part of the basin (Kolindros area) the main faults follow the NE-SW to ENE-WSW, NW-SE and E-W directions.

The significant change in the flow direction of the main streams in the central part of the basin is most probably attributable to the activity of an important ENE-WSW fault, as well as to the existence of minor NW-SE conjugate faults. Near the coastal area of Makrygialos (eastern part of the basin), the NE-SW and NNW-SSE faults have dislocated the layers of Makrygialos Fm up to 10m (Sylvestrou, 2002), indicating their post-Pliocene activity. In the same area, a strike-slip fault has been identified by Faugeres (1975), while Sylvestrou (2002) detected two major NE-SW and NWSE faults, which have affected all recent deposits. In the area of Methoni, a NE-SW normal fault, that was active during Lower Holocene (Faugeres, 1975), affected the Quaternary sediments.

\section{Geothermal Investigation}

The preliminary-reconnaissance geothermal investigation in the basin of Katerini mainly regarded temperature measurements at the wellhead of 73 water wells during pumping (Fig.2). The geothermal gradient was calculated by temperature measurements in the interior of five (5) boreholes and from available temperature data from past measurements in three (3) water wells. Water sampling and chemical analyses from 18 selected sites was also conducted.

The most important aquifers in the basin are found inside layers with coarse material, e.g. conglomerates and gravels, whereas the discharge from fine-grained sandy aquifers is significantly lower. The flow-rate from the wells in the central part of the basin (Alykes Kitrous-KorinosKaterini-Kallithea) ranges from 20 to $150 \mathrm{~m}^{3} / \mathrm{h}$, depending on the aquifer characteristics. The depth of the wells in the hilly zone is $30-416 \mathrm{~m}$. In this area, the aquifers are located inside layers of sand or pebbles and in limestones, with generally lower water discharge $\left(20-100 \mathrm{~m}^{3} / \mathrm{h}\right)$.

\subsection{Wellhead temperatures}

The exact location of the measured wells and the corresponding isothermal curves are illustrated in the maps of Fig. 2 and Fig. 3, respectively. Based on the distribution of wellhead temperatures and the shape of the contours, three (3) sub-regions of geothermal interest can be defined: (a) Kato Agios Ioannis, (b) Sevasti, and (c) the area between Kitros-Alykes Kirtou-Makrygialos.

The maximum recorded temperature in the area of Kato Agios Ioannis was $24.8^{\circ} \mathrm{C}$ (Table 1) in the $\Lambda \Theta-23$ well, which is located $300 \mathrm{~m}$ northwards of the settlement. The isothermal curves generally trend NNW-SSE (Fig.), however, the thermal anomaly probably extends to the ENE of the village, as it is indicated by the temperatures of $\Lambda \Theta-27$ and $\Lambda \Theta-29$ wells. This is probably related to the existence of a W-E fault, which crosses through the village and continues to the east (Mettos et al., 1986).

The geothermal anomaly near Sevasti village extends to the NNE, SE, S and SW of the settlement, as well as in the area between Sevasti and Nea Trapezounta. The wellhead temperatures vary from 18.0 to $20.7^{\circ} \mathrm{C}$ (Table 1$)$.

The temperatures in the region Kitros-Alykes Kitrous-Makrygialos do not exceed $18.3^{\circ} \mathrm{C}$ (Table 1). However, according to past measurements in the interior of the well $\mathrm{A} \Lambda-1$ (located very close to $\Lambda \Theta-63)$, the temperature at the depth of $108 \mathrm{~m}$ was $19.6^{\circ} \mathrm{C}\left(3.79^{\circ} \mathrm{C} / 100 \mathrm{~m}\right)$. The distribution of temperatures in this region is determined by the local tectonic regime, as it is suggested by the shape and trending of the $18^{\circ} \mathrm{C}$ contour, which follows the direction of two parallel NW-SE faults between Kitros and Thermaikos coast (Mettos et al., 1986). 


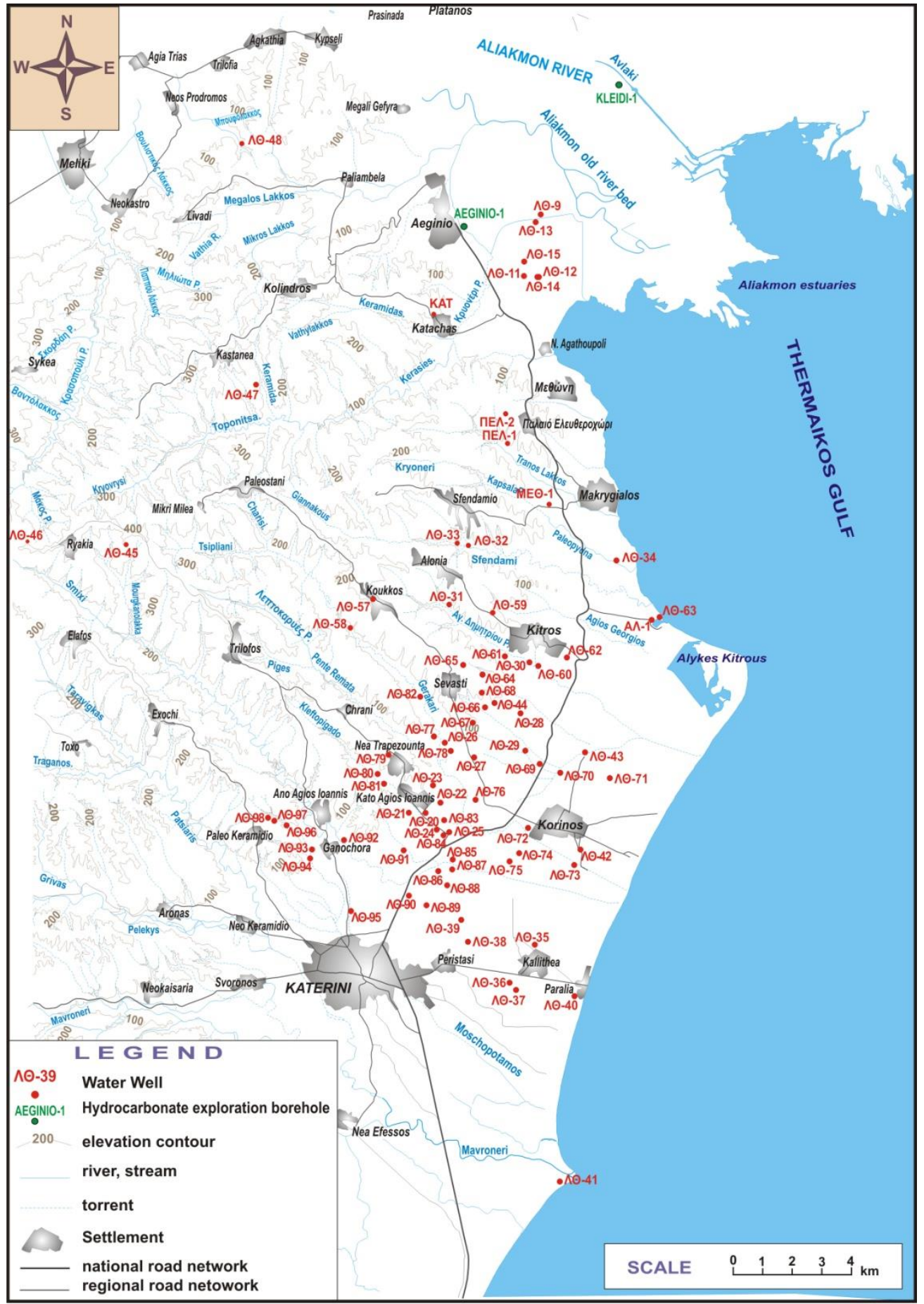

Figure 2 - Topographic map indicating the measured water wells (source: Kolios et al., 2005). 
Table 1 - Wellhead temperatures in the 3 regions of geothermal interest (well depth $>150 \mathrm{~m}$ ).

\begin{tabular}{|c|c|c|c|c|c|}
\hline Well & $\begin{array}{c}\text { Depth } \\
\text { (m) }\end{array}$ & $\begin{array}{c}\text { Wellhead } \\
\text { Temperature } \\
\left({ }^{\circ} \mathrm{C}\right)\end{array}$ & Well & Depth (m) & $\begin{array}{c}\text { Wellhead } \\
\text { Temperature } \\
\left({ }^{\circ} \mathrm{C}\right)\end{array}$ \\
\hline \multicolumn{3}{|c|}{ Kato Agios Ioannis } & \multicolumn{3}{|c|}{ Sevasti } \\
\hline$\Lambda \Theta-20$ & 248 & 23.5 & $\Lambda \Theta-28$ & 170 & 19.2 \\
\hline$\Lambda \Theta-21$ & 180 & 21.8 & $\Lambda \Theta-26$ & 138 & 18.0 \\
\hline$\Lambda \Theta-22$ & 245 & 21.0 & $\Lambda \Theta-64$ & 150 & 18.3 \\
\hline$\Lambda \Theta-23$ & 416 & 24.8 & $\Lambda \Theta-65$ & 260 & 20.7 \\
\hline$\Lambda \Theta-24$ & 238 & 23.2 & $\Lambda \Theta-66$ & 198 & 20.7 \\
\hline$\Lambda \Theta-27$ & 150 & 21.1 & $\Lambda \Theta-67$ & 190 & 19.7 \\
\hline$\Lambda \Theta-29$ & 300 & 21.3 & $\Lambda \Theta-68$ & 210 & 18.4 \\
\hline$\Lambda \Theta-39$ & 314 & 22.0 & $\Lambda \Theta-77$ & 197 & 19.7 \\
\hline$\Lambda \Theta-81$ & 187 & 20.7 & $\Lambda \Theta-78$ & 260 & 20.4 \\
\hline$\Lambda \Theta-84$ & 238 & 23.5 & & & \\
\hline \multicolumn{6}{|c|}{ Kitros- Alykes Kitrous-Makrygialos } \\
\hline$\Lambda \Theta-34$ & 120 & 18.2 & $\Lambda \Theta-63$ & 167 & 18.3 \\
\hline$\Lambda \Theta-62$ & 200 & 18.0 & & & \\
\hline
\end{tabular}

\subsection{Geothermal gradients}

The geothermal gradients in the study area have been calculated by temperature measurements inside five (5) boreholes (Fig. 4) and from available literature data. According to the recordings from the meteorological station of Katerini for the period (1951-1996) (Tzimourtas, 2001), the mean annual air temperature that has been taken into account for the gradient calculation, is $15^{\circ} \mathrm{C}$ for the plain areas and $14.1-15.0^{\circ} \mathrm{C}$ for the hilly zone.

The wells $\Lambda \Theta-12$ and $\Lambda \Theta-15$ are located at the northern borders of the basin, south-eastern wards of Aeginio town. The temperature recorded at the bottom $(129 \mathrm{~m})$ of the artesian well $\Lambda \Theta-15$ is $18.8^{\circ} \mathrm{C}$ and the resulting geothermal gradient is $2.56^{\circ} \mathrm{C} / 100 \mathrm{~m}$. The temperatures up to the depth of $10 \mathrm{~m}$ in the well $\Lambda \Theta-12$ are very low, reflecting the influence of cold superficial aquifers. For that reason, the geothermal gradient was calculated for the depth interval $20-75 \mathrm{~m}$ and is $3.09^{\circ} \mathrm{C} / 100$, i.e. similar to the mean value.

The bottomhole $(2475 \mathrm{~m})$ temperature in the hydrocarbon exploration borehole AEGINIO-1 is $79.5^{\circ} \mathrm{C}$ (S.P.E.G., $1982 \mathrm{~b}$ ) and the average geothermal gradient is $2.58^{\circ} \mathrm{C} / 100 \mathrm{~m}$; it should, however, be mentioned that the gradient for the interval $0-1814 \mathrm{~m}$ is much lower, i.e. $1.74^{\circ} \mathrm{C} / 100 \mathrm{~m}$. The temperature recorded at the depth of $385 \mathrm{~m}$ in the well KAT (southern wards of Aeginio town) is $23.6^{\circ} \mathrm{C}$, indicating a geothermal gradient of $2.1^{\circ} \mathrm{C} / 100 \mathrm{~m}$.

The well $\Lambda \Theta-48$ is located at the northern part of the hilly zone. The temperature at the depth of $285 \mathrm{~m}$ is $18.7^{\circ} \mathrm{C}$. Temperature inversion is observed up to the depth of $50 \mathrm{~m}$, attributable to lateral intrusion of cold water. The geothermal gradient that corresponds to the interval $50-285 \mathrm{~m}$ is $1.7^{\circ} \mathrm{C} / 100 \mathrm{~m}$. 


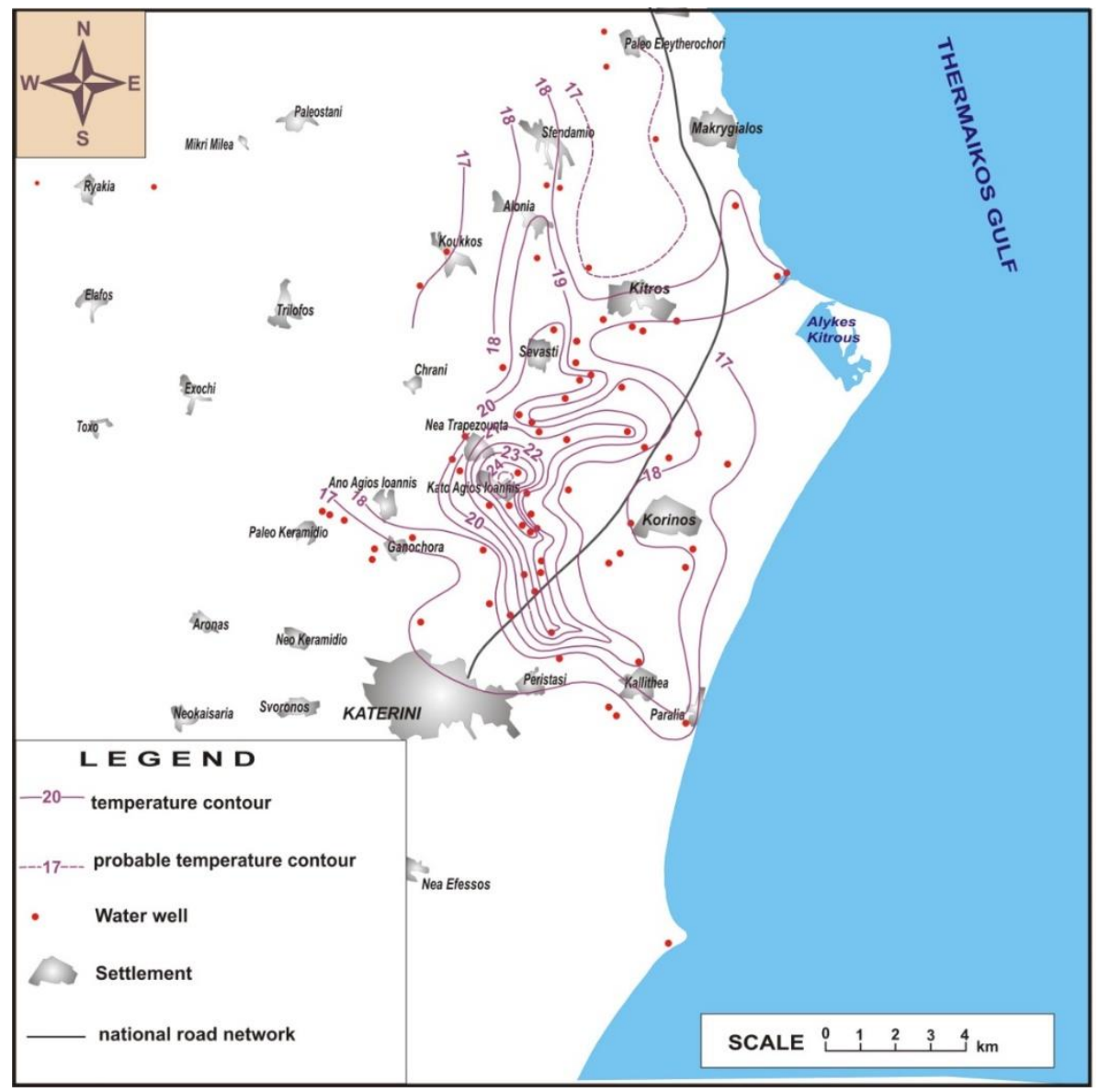

Figure 3 - Temperature contours based on wellhead temperatures (well depth $>150 \mathrm{~m}$ ).

The well $\Lambda \Theta-47$ is located about $6 \mathrm{~km}$ southern wards of $\Lambda \Theta-48$, at elevation $233 \mathrm{~m}$. According to the temperature logs (Kolios et al., 2005), $24.0^{\circ} \mathrm{C}$ have been recorded at the depth of $380 \mathrm{~m}$. The temperature inversion that is observed at the depth interval $60-85 \mathrm{~m}$ is attributed to the lateral inflow of cold water from the screen casing between $72-78 \mathrm{~m}$. The slope of the temperature curve changes after the depth of $230 \mathrm{~m}$, indicating different rates of increasing temperature with respect to depth, i.e. $0.92^{\circ} \mathrm{C} / 100 \mathrm{~m}(100-230 \mathrm{~m})$ and $3.0^{\circ} \mathrm{C} / 100 \mathrm{~m}(230-280 \mathrm{~m})$, with the latter being considered as the characteristic gradient for the specific well.

The calculation of geothermal gradient in the area of Sevasti is based on the temperatures in the $\Lambda \Theta-$ 44 well. The maximum recorded value was $24.7^{\circ} \mathrm{C}$ at the depth of $270 \mathrm{~m}$. According to the temperature profile, three individual curve parts are observed, which correspond to the depths 50$150 \mathrm{~m}, 150-250 \mathrm{~m}$ and $250-270 \mathrm{~m}$. The rate of temperature increase with depth is $0.5^{\circ} \mathrm{C} / 100 \mathrm{~m}$, $7.1^{\circ} \mathrm{C} / 100 \mathrm{~m}$ and $2^{\circ} \mathrm{C} / 100 \mathrm{~m}$, respectively. The average gradient for the total depth is $3.6^{\circ} \mathrm{C} / 100 \mathrm{~m}$.

In the area near the village Kato Agios Ioannis, a rough estimate of the geothermal gradient is based upon past measurements in the well $\Lambda \Theta-23$, according to which, the temperatures at the depth of $340 \mathrm{~m}$ was $26.7^{\circ} \mathrm{C}$. Taking into account the mean annual air temperature at $15.5^{\circ} \mathrm{C}$, the geothermal gradient is calculated at $3.3^{\circ} \mathrm{C} / 100 \mathrm{~m}$. Similarly, for the area Kitros-Alykes Kitrous, the temperature at the depth of $108 \mathrm{~m}$ in the well $\mathrm{A} \Lambda-1$, indicates a geothermal gradient of $3.8^{\circ} \mathrm{C} / 100 \mathrm{~m}$. 


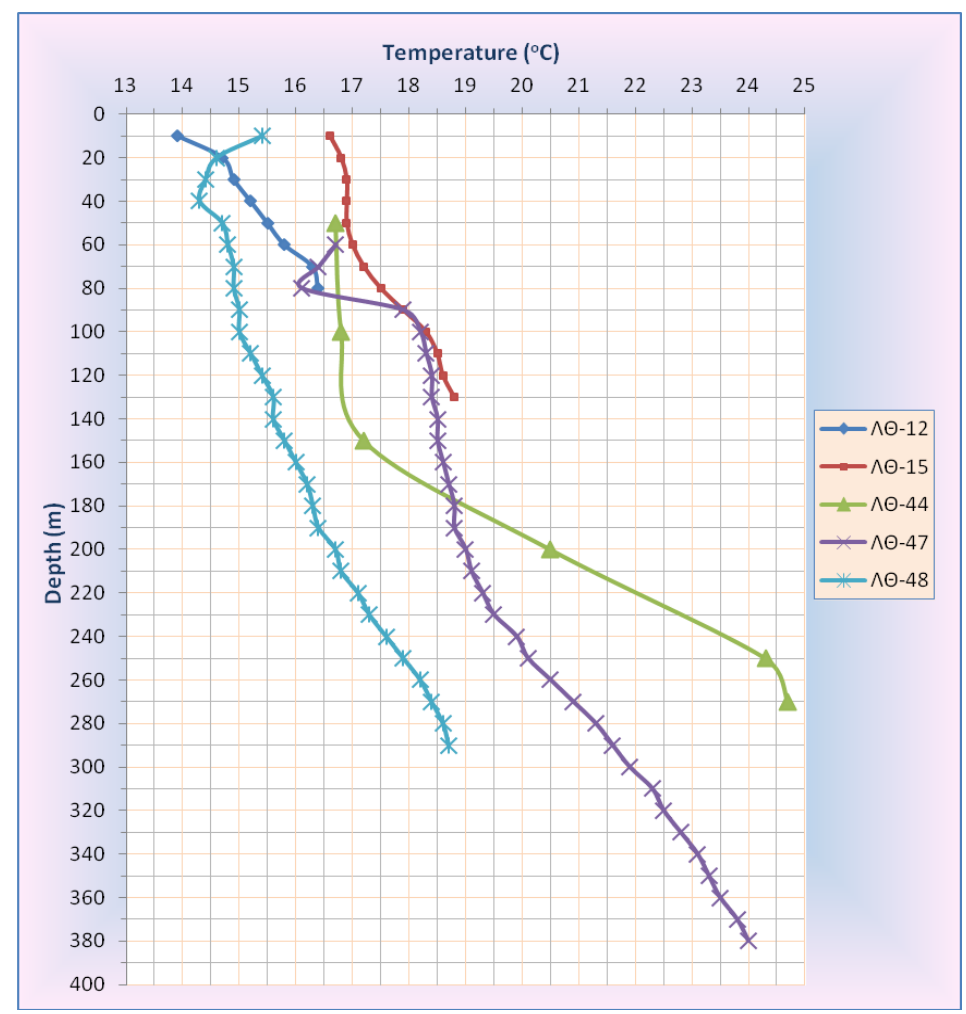

Figure 4 - Temperature profiles from wells in Katerini Basin.

\section{Geochemical investigation}

In the area eastwards of Aeginio (Figure 2), waters at temperatures of $18.0-20.5^{\circ} \mathrm{C}$ are classified as $\mathrm{Mg}, \mathrm{Ca}-\mathrm{HCO}_{3}, \mathrm{Na}-\mathrm{HCO}_{3}$ and $\mathrm{Na}-\mathrm{HCO}_{3} \mathrm{Cl}$ types (Figure 5A). They have TDS contents of $0.84-1.81$ $\mathrm{g} / \mathrm{l}$ and show $\mathrm{pH}$ values of 7.59-7.94 (alkaline waters). The water sample $\Lambda \Theta-14$ is of the Na$\mathrm{HCO}_{3} \mathrm{Cl}$ type and is characterized by higher TDS level $(1.81 \mathrm{~g} / \mathrm{l})$. It is rich in $\mathrm{Na}^{+}(600 \mathrm{mg} / \mathrm{l})$ and $\mathrm{Cl}^{-}$ $(583.6 \mathrm{mg} / \mathrm{l})$, which indicates the influence of sea water. The neighbouring wells $\Lambda \Theta-11$ and $\Lambda \Theta-$ 15 yield waters of $\mathrm{Na}-\mathrm{HCO}_{3}$ and $\mathrm{Mg}, \mathrm{Ca}-\mathrm{HCO}_{3}$ types respectively, with lower salinities.

The water samples southwards of Aeginio are classified as $\mathrm{Ca}, \mathrm{Mg}, \mathrm{Na}-\mathrm{HCO} 3, \mathrm{Na}, \mathrm{Mg}-\mathrm{HCO} 3, \mathrm{Ca}-$ $\mathrm{HCO}_{3}$ and $\mathrm{Ca}-\mathrm{HCO}_{3}$ types (Figure $5 \mathrm{~B}$ ). The analyses of the samples from the wells that are located in the lowland and hilly areas of the basin $(\Lambda \Theta-20, \Lambda \Theta-21, \Lambda \Theta-22, \Lambda \Theta-24, \Lambda \Theta-25, \Lambda \Theta-26, \Lambda \Theta-30$, $\Lambda \Theta-31, \Lambda \Theta-32, \Lambda \Theta-33$ and $\Lambda \Theta-34)$, indicated groundwater of the $\mathrm{Ca}, \mathrm{Mg}, \mathrm{Na}-\mathrm{HCO}_{3}$ type. The wellhead temperatures vary from 16.5 to $23.5^{\circ} \mathrm{C}$. The TDS is in the range of $0.47-0.73 \mathrm{~g} / \mathrm{l}$ and the $\mathrm{pH}$ of 7.29-7.96 (alkaline waters). $\mathrm{Ca}^{2+}, \mathrm{Mg}^{2+}$ and $\mathrm{Na}^{+}$contribute by $21.8-51.4 \%, 29.1-47.4 \%$ and $18.4-42 \%$, respectively, to the total cationic charges (in meq/l). Their concentrations have been determined to be 45.7-96.2 mg/l Ca${ }^{2+}$, 29.1-47.4 mg/l Mg${ }^{2+}$ and 53-108 mg/l $\mathrm{Na}^{+}$. The dominant anion is $\mathrm{HCO}_{3}-(370.9-539.2 \mathrm{mg} / \mathrm{l})$ constituting $62.9-77.5 \%$ of the total anionic charges. $\mathrm{The}^{-} \mathrm{SiO}_{2}$ contents range from 14.2 to $30.8 \mathrm{mg} / \mathrm{l}$.

The water samples from $\Lambda \Theta-23(\mathrm{~A} \Gamma-1), \Lambda \Theta-27, \Pi \mathrm{E} \Lambda-1$ and $\mathrm{A} \Lambda-1$ belong to the $\mathrm{Na}, \mathrm{Mg}-\mathrm{HCO}_{3}$ type. Their temperatures range from $19.6-24.8^{\circ} \mathrm{C}$. They have low TDS $(0.42-0.54 \mathrm{~g} / \mathrm{l})$ and alkaline character $(\mathrm{pH}=7.45-7.88) . \mathrm{Na}^{+}$and $\mathrm{Mg}^{2+}$ contribute to the total cationic charges (in meq/l) by 33.558.5\% and 23.3-48.8\%, respectively. The corresponding $\mathrm{Na}^{+}$and $\mathrm{Mg}^{2+}$ concentrations are 70-110 $\mathrm{mg} / \mathrm{l}$ and $22.4-54 \mathrm{mg} / \mathrm{l}$. The dominant anion is $\mathrm{HCO}_{3-}(341.6-386.7 \mathrm{mg} / \mathrm{l})$, contributing by 64.7$81.6 \%$ to the total anionic charges. The samples $\Lambda \Theta-23(\mathrm{~A} \Gamma-1)$ and $\Lambda \Theta-27$ are plotted on the 
boundary line between $\mathrm{Na}, \mathrm{Mg}-\mathrm{HCO}_{3}$ and $\mathrm{Ca}, \mathrm{Mg}, \mathrm{Na}-\mathrm{HCO}_{3}$ types. The well $\mathrm{A} \Lambda-1$ yields water of $\mathrm{Na}, \mathrm{Mg}-\mathrm{HCO}_{3}$ type, despite its vicinity with the sea.

In the western part of the basin, close to the village of Ryakia, the wells $\Lambda \Theta-45$ and $\Lambda \Theta-46$ yield waters of $\mathrm{Na}-\mathrm{HCO}_{3}$ and $\mathrm{Ca}-\mathrm{HCO}_{3}$ types, respectively (Figure $5 \mathrm{~B}$ ). The temperature of the $\Lambda \Theta-45$ well is $18.1^{\circ} \mathrm{C}$. The water is slightly alkaline $\mathrm{pH}(7.6)$ with TDS at $0.39 \mathrm{~g} / \mathrm{l}$. The water from the $\Lambda \Theta-$ 46 well has low temperature $\left(14.8^{\circ} \mathrm{C}\right)$, low TDS $(0.39 \mathrm{~g} / \mathrm{l})$ and neutral $\mathrm{pH}(6.96)$. The dominant cation is $\mathrm{Ca}^{2+}(124.9 \mathrm{mg} / \mathrm{l}, 82.2 \%$ of the total cationic charge). This sample can be considered as the most representative cold water in the basin that comes from a shallow aquifer.

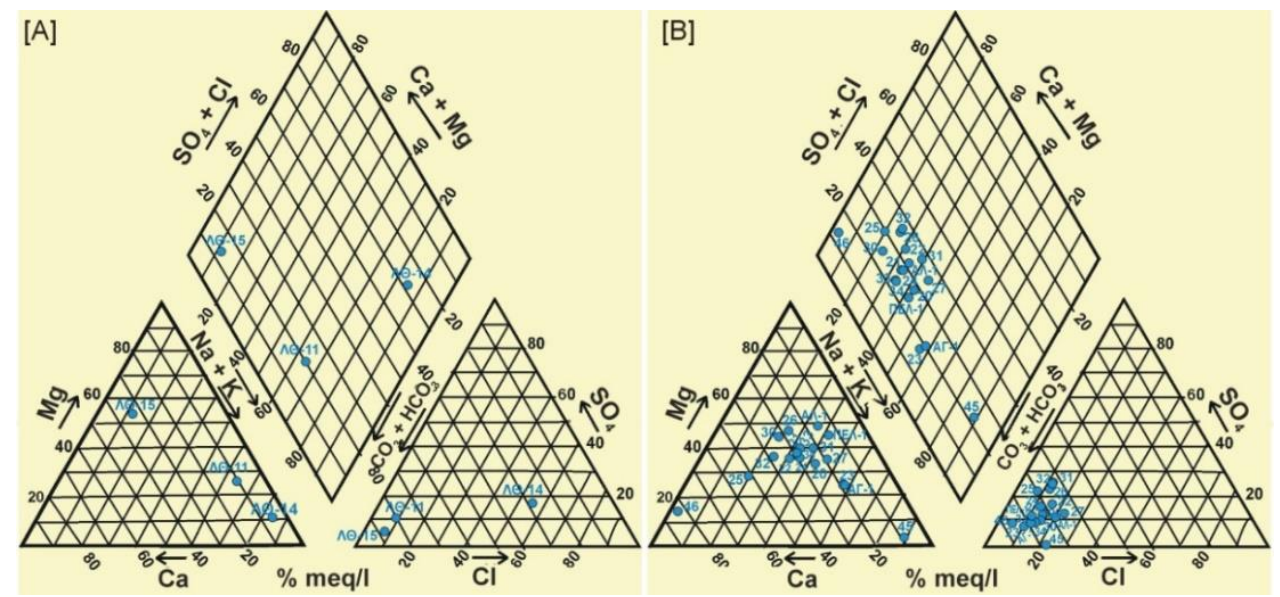

Figure 5 - Piper (1944) trilinear diagram of groundwaters from (A) the Aeginio - Nea Agathoupoli area and (B) southwards of Aeginio.

The composition of groundwater is defined by geochemical processes and factors, such as the dissolution of carbonate, silicate and clay minerals, feldspars and mica. The cold waters of the wider area are enriched in $\mathrm{Ca}^{2+}$ and $\mathrm{Mg}^{2+}$, due to their circulation in shallow aquifers composed of sandstones, sands and pebbles. The increased $\mathrm{Ca}^{2+}$ and $\mathrm{Mg}^{2+}$ concentrations in shallow and cold waters can be attributed to the dissolution of carbonate minerals, which constitute the cement of the clastic sediments. Fluctuation of $\mathrm{Ca}^{2+}$ concentrations in the groundwater is either attributable to different residence time within the sediments or to the lithological differentiation of the formations through which the groundwater has circulated. The $\mathrm{Na}^{+}$cations are derived from the dissolution of the plagioclase feldspars and clay minerals. Waters coming from deeper aquifers (sands and pebbles), which are interbedded among clayey sediments, show higher $\mathrm{Na}^{+}$contents. Hence, the water samples from the wells located in the lowland and hilly areas of the Katerini basin belong to the $\mathrm{Ca}, \mathrm{Mg}, \mathrm{Na}-\mathrm{HCO}_{3}$ and $\mathrm{Na}, \mathrm{Mg}-\mathrm{HCO}_{3}$ types. The increased concentrations of $\mathrm{Na}^{+}$and $\mathrm{HCO}_{3}{ }^{-}$can be attributed to the combined effect of calcite/dolomite dissolution and the $\mathrm{Ca}-\mathrm{Na}$ ion-exchange controlled by the presence of clay minerals. These geochemical processes result in the formation of $\mathrm{Na}$-enriched waters. The correlation diagrams show that the concentrations of various chemical species $\left(\mathrm{Na}^{+}, \mathrm{K}^{+}, \mathrm{SiO}_{2}, \mathrm{Cl}-, \mathrm{Ca}^{2+}, \mathrm{HCO}_{3}{ }^{-}\right.$, $\mathrm{CO}_{3}{ }^{2-}, \mathrm{NH}_{4}{ }^{+}, \mathrm{SO}_{4}{ }^{2-}, \mathrm{Mg}^{2+}, \mathrm{B}, \mathrm{F}^{-} \kappa \alpha \mathrm{Br}$ ) is not associated to the water temperature.

\section{Discussion-Conclusions}

The results of the reconnaissance geothermal investigation in the basin of Katerini suggest three individual sub-regions of geothermal interest, which, in order of priority, are: (i) the area of Kato Agios Ioannis, (ii) the area of Sevasti, and (iii) the area between Kitros-Alykes Kitrous and Makygialos.

The maximum temperatures were recorded near the village of Kato Agios Ioannis, where $26.7^{\circ} \mathrm{C}$ were recorded at the depth of $340 \mathrm{~m}$. The geothermal gradient of $3.29^{\circ} \mathrm{C} / 100 \mathrm{~m}$ in this area is slightly higher than the mean earth value. The temperature contours generally trend NNW-SSE, but, evidently, the thermal anomaly is extending to the east, probably due to the existence of a W-E fault. 
The calculated geothermal gradient near Sevasti is $3.67^{\circ} \mathrm{C} / 100$, based upon measurements in only one well. Nevertheless, the wellhead temperatures, which vary from $19.2-20.7^{\circ} \mathrm{C}$, are lower than in the region of Kato Agios Ioannis, where they reach $24.8^{\circ} \mathrm{C}$.

The area between Sevasti and Nea Trapezounta seems less promising, with the wellhead temperatures not exceeding $20.4^{\circ} \mathrm{C}$. The wellhead temperatures in the area Kitros-Alykes KitrousMakrygialos are $18-18.2^{\circ} \mathrm{C}$; however the temperature of $19.6^{\circ} \mathrm{C}$ at the depth of $108 \mathrm{~m}$, which was measured in one well, indicates a geothermal gradient $\left(3.8^{\circ} \mathrm{C} / 100 \mathrm{~m}\right)$ above the mean earth value.

The chemical analyses showed that the groundwater of Katerini basin is classified as $\mathrm{Ca}, \mathrm{Mg}$, Na$\mathrm{HCO}_{3}$ and $\mathrm{Na}, \mathrm{Mg}-\mathrm{HCO}_{3}$ water. No correlation between ions and temperature could be established, which means that the chemical character of the groundwater in this area mostly depends on the local lithology and mineral composition.

The geological structure and the stratigraphy of the basin specify the thickness of the Neogene sediments to more than $1000 \mathrm{~m}$, which benefits the drilling of deep exploration boreholes. Given the estimated geothermal gradients, significant temperatures could be encountered before entering the bedrock formations.

The available data suggest that the systematic geothermal and drilling exploration should initially focus on the area of Kato Agios Ioannis. On the other hand, the exploitation of the shallow and high yield aquifers from existing water wells (by using geothermal heat pumps), which could be immediately realised, constitutes an efficient and cost effective solution for the heating and/or cooling of a building, pool, greenhouse, etc.

\section{Acknowledgements}

This paper presents the results of the project "Exploration and identification of geothermal fields in the basin of Thessaloniki", conducted by IGME in the frame of the $3^{\text {rd }}$ Community Support Framework 2000-2006 (Operational Programme "Competitiveness").

\section{References}

Benda, L. and Steffens, P., 1981. Aufbau und Alter des Neogens von Katerini (Griechenland), Geol. $J b .$, B42, 93-103.

Faugeres, L., 1977. Naissance et développement du relief de 1'Olympe (Grèce): une manifestation éclatante de la tectonique récente, Rev. Géogr. Phys. et Géol. Dyn, 19(1), 7-26.

Kolios, N., Koutsinos, S., Kougoulis, C., Arvanitis, A. and Karydakis, G., 2005. Exploration and identification of geothermal fields in the Thessaloniki basin, Report, IGME, Thessaloniki, 109-204 (in greek).

Kottek, M., Grieser, J., Beck, C., Rudolf, B. and Rubel, 2006. World Map of the Koppen-Geiger climate classification updated, Meteorologische Zeitschrift, 15(3), 265-263.

Mettos, A., Koutsouveli, A., Tsapralis, V. and Ioakim, C., 1986. Geological Map of Greece - Scale 1:50,000 - Sheet KATERINI, IGME, Athens.

Mountrakis, D., 1985. Geology of Greece, Thessaloniki, University Studio Press, 208 pp.

Piper, A.M., 1944. A graphic procedure in the geochemical interpretation of water analysis, Trans. Amer. Geophysical Union, 25, 914-928.

S.P.E.G. (Société de Prospection et d'Etudes Géothermiques), 1982. Evaluation du potential géothermique des bassins Tertaire du Nord de le Grèce, Annexes.

Sylvestrou, I., 2002. Stratigraphic, Paleontological and Palaeogeographical Study of the NeogeneQuaternary Deposits of Katerini basin, Northern Greece, PhD Thesis, Aristotle University of Thessaloniki, Thessaloniki, $339 \mathrm{pp}$.

Tzimourtas, S., 2001. Hydrogeological exploration of carbonate formations in Central Macedonia, Mount Olympus area, Report, IGME, Thessaloniki, $61 \mathrm{pp}$. 